\title{
Physiological and enzymatic changes in soybean seeds submitted to harvest delay ${ }^{1}$
}

\author{
Alan Mario Zuffo 2 , Joacir Mario Zuffo Júnior ${ }^{3}$, \\ Everson Reis Carvalho ${ }^{4}$, Fábio Steiner ${ }^{2}$, Everton Vinicius Zambiazzi ${ }^{5}$
}

\section{ABSTRACT}

Harvest delay may affect the physiological quality of soybean seeds due to the occurrence of unfavorable environmental conditions in the field. This study was conducted to investigate the physiological and enzymatic changes in soybean seeds submitted to harvest delay. A randomized block design, with eight seed harvest periods $(0 ; 5 ; 10 ; 15 ; 20 ; 25$; 30 ; and 35 days after the $\mathrm{R}_{8}$ phenological stage - full maturity) of the BRS $820 \mathrm{RR}^{\circledR}$ cultivar, with four replicates, was used. At each harvest period, the moisture content, 1,000-seed weight, germination, seedling emergence, emergence speed index, accelerated aging, vigor and viability (tetrazolium test), electrical conductivity, enzymatic expression and seed yield were measured. Harvest delay up to 35 days after the $\mathrm{R}_{8}$ phenological stage do not affect the 1,000 -seed weight and seed yield. The delayed harvest from the $\mathrm{R}_{8}$ stage results in increased damage by stink bugs and moisture. The harvest delay of seeds from the 10th day after the $R_{8}$ stage impairs the seed vigor and, from the 15 th day, seed germination. Seeds harvested with a delay after the $\mathrm{R}_{8}$ stage have lower expressions of the following isoenzymatic systems: malate dehydrogenase, alcohol dehydrogenase, esterase, isocitrate lyase and superoxide dismutase, especially after 15 days of harvest delay.

KEYWORDS: Glycine $\max ($ L.) Merrill; seed deterioration; harvest period.

\section{INTRODUCTION}

Soybean [Glycine $\max (\mathrm{L}$.$) Merrill] is one$ of the most important oil crops in the entire world. Brazil is one of the largest producers and exporters of soybean in the world, with a planted area of 33.9 million hectares and production of 114.1 million tons in the 2016/2017 growing season (Conab 2017). For Brazil to maintain these high levels of production, the seed market is extremely relevant, since one of the

\section{RESUMO}

Alterações fisiológicas e enzimáticas em sementes de soja submetidas a atraso de colheita

$\mathrm{O}$ atraso da colheita pode afetar a qualidade fisiológica das sementes de soja, devido à ocorrência de condições adversas no campo. Objetivou-se avaliar as alterações fisiológicas e enzimáticas em sementes de soja submetidas a atraso de colheita. Utilizou-se delineamento em blocos casualizados, com oito épocas de colheita de sementes da cultivar BRS $820 \operatorname{RR}^{\circledR}(0 ; 5 ; 10 ; 15 ; 20 ; 25 ; 30 ;$ e 35 dias após o estádio fenológico $\mathrm{R}_{8}$ - maturação plena), com quatro repetições. Em cada período de colheita, foram mensurados o grau de umidade, peso de mil sementes, germinação, emergência, índice de velocidade de emergência, envelhecimento acelerado, vigor e viabilidade (teste de tetrazólio), condutividade elétrica, expressão enzimática e produtividade. A produtividade e a massa de mil sementes de soja não são afetadas pelo atraso de colheita até 35 dias após $\mathrm{R}_{8}$. $\mathrm{O}$ atraso de colheita, a partir do estádio $\mathrm{R}_{8}$, promove aumento nos danos provocados por percevejos e pela umidade. O retardamento da colheita de sementes a partir de 10 dias após $\mathrm{R}_{8}$ prejudica $\mathrm{o}$ vigor das sementes e, a partir de 15 dias, a germinação. Sementes colhidas com retardamento de colheita após $\mathrm{R}_{8}$ apresentam menores expressões dos sistemas isoenzimáticos malato desidrogenase, álcool desidrogenase, esterase, isocitrato liase e superóxido dismutase, principalmente após 15 dias de atraso de colheita.

PALAVRAS-CHAVE: Glycine max (L.) Merrill; deterioração de sementes; período de colheita.

main limiting factors for obtaining high grain yields is associated with the physiological quality of the seeds used (Carvalho et al. 2014b).

In the process of seed production, all steps involved are relevant to obtain high quality seeds and, for the soybean crop, the harvest time is one of the critical steps. During physiological maturity $\left(\mathrm{R}_{7}\right.$ phenological stage), soybean seeds have the greatest physiological quality, with moisture content around 30-65\%, what makes mechanized harvest infeasible 
(Sediyama 2016). The seed viability period depends on both genetic characteristics and environmental effects during the development stages, harvest, processing and storage. When unfavorable conditions occur in any of these phases, physiological damage may result in damage to seed quality (Gris et al. 2010).

Soybean should be harvested as soon as seed moisture content comes to a level suitable for mechanical harvest. Combining harvesters available in the Brazilian market may only operate efficiently when plants are at the $\mathrm{R}_{8}$ stage (when $95 \%$ of pods have the typical coloration of mature pods or full maturity), as described by Fehr et al. (1971). However, in many cases, the appropriate harvest time is exceeded due to the extension of the area and insufficient quantity of harvesters, or due to unavoidable delays when high rainfall rates occur during harvest. In these cases, the seeds are exposed in the field for longer periods.

Studies that address this topic show controversial results, besides being carried out with old cultivars, which nowadays are no longer sown in substantial acreage. With the delayed harvest, damage to the quality of seeds has its intensity affected by genetic factors intrinsic to each cultivar (Gris et al. 2010), among others. Cultivars tolerate harvest delays differently (Diniz et al. 2013a). Thus, due to the dynamics of the plant genetic breeding of soybean cultivars, new research is needed.

Another important factor in the natural deterioration process of soybean seeds is the time of exposition of seeds in the field after the physiological maturity (Diniz et al. 2013a). Diniz et al. (2013b) stated that a harvest delay of 30 days affects germination. Xavier et al. (2015) emphasized that seeds harvested at the $\mathrm{R}_{8}$ stage have a higher physiological quality than those harvested at 7 ; 14; 21; and 28 days after this stage. However, the intensity of these negative effects depends on the time that seeds remain in the field, genotype and climatic conditions, such as temperature and rainfall. The decrease of soybean seed quality in the field involves physical, chemical and physiological changes, as well as damage caused by microorganisms (Zuffo et al. 2017). Minuzzi et al. (2010) concluded that the highest seed quality can be obtained by performing the harvest at 7 days after the physiological maturity.

In the period between physiological maturity and harvest of soybean seeds, damage from alternating wet and dry environmental conditions may occur, which may be more significant in tropical regions, due to the predominantly hot and humid climate (Castro et al. 2016).

Given the importance of seed quality in achieving high levels of soybean yield for the Brazilian agriculture, this study aimed to investigate the physiological and enzymatic changes in soybean seeds associated with harvest delay.

\section{MATERIAL AND METHODS}

The experiment was carried out at the Fazenda Muquém, in Lavras, Minas Gerais state, Brazil $\left(21^{\circ} 14^{\prime} \mathrm{S}, 45^{\circ} 00^{\prime} \mathrm{W}\right.$ and altitude of $\left.918 \mathrm{~m}\right)$, in the $2013 / 2014$ growing season. The tests of physiological quality and enzymatic expression were carried out at the seed laboratory of the Universidade Federal de Lavras.

The soil of the experimental area is classified as Rhodic Hapludox, and the physical and chemical properties (Table 1) were determined by adopting standard procedures. During the growing season of the soybean crop, data concerning air temperature, relative humidity and rainfall were collected from an automatic weather station of the Brazilian National Institute of Meteorology (Figure 1A), and climatic conditions during seed harvest periods are shown in Figure 1B.

Soybean [Glycine max L. (Merrill.), cv. BRS $\left.820 \mathrm{RR}^{\circledR}\right]$ was sown on 15 November 2013, in $0.50-\mathrm{m}$ rows, at a rate of 14 seeds $\mathrm{m}^{-1}$. Seeds were

Table 1. Chemical and physical properties (0.0-0.20 m layer) of the soil before the beginning of the experiment.

\begin{tabular}{|c|c|c|c|c|c|c|c|c|c|c|}
\hline $\mathrm{pH}$ & $\mathrm{Ca}^{2+}$ & $\mathrm{Mg}^{2+}$ & $\mathrm{Al}^{3+}$ & $\mathrm{H}^{+}+\mathrm{Al}^{3+}$ & SB & CEC & $\mathrm{P}$ & $\mathrm{K}$ & $\mathrm{OM}$ & $\mathrm{V}$ \\
\hline $\mathrm{H}_{2} \mathrm{O}$ & & & $\mathrm{cm}$ & $\mathrm{dm}^{-3}-$ & & & $-\mathrm{mg} \mathrm{d}$ & -3 & dag kg-1 & $\%$ \\
\hline 6.4 & 5.0 & 1.4 & 0.0 & 2.9 & 6.7 & 9.6 & 11.46 & 118 & 3.41 & 70 \\
\hline $\mathrm{Zn}$ & $\mathrm{Mn}$ & $\mathrm{Cu}$ & $\mathrm{B}$ & $\mathrm{Fe}$ & $\mathrm{S}$ & Clay & Silt & & \multirow{2}{*}{\multicolumn{2}{|c|}{$\begin{array}{c}\text { Textural } \\
\text { class }\end{array}$}} \\
\hline \multicolumn{6}{|c|}{$\mathrm{mg} \mathrm{dm}^{-3}$} & \multicolumn{3}{|c|}{ dag kg $^{-1}$} & & \\
\hline 4.97 & 31.70 & 1.40 & 0.17 & 34.81 & 4.75 & 64 & 20 & & \multicolumn{2}{|r|}{ Clayey } \\
\hline
\end{tabular}



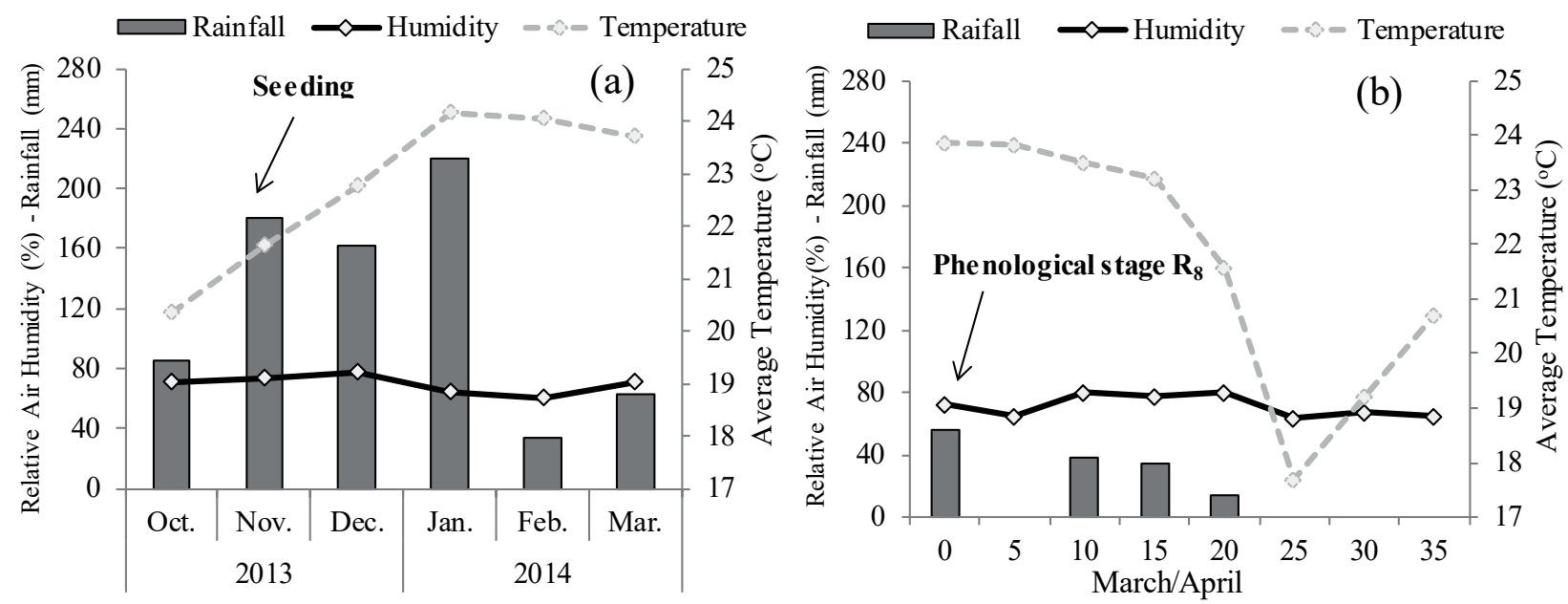

Figure 1 . Total monthly rainfall, relative humidity and average air temperature, in the $2013 / 2014$ crop season, during the soybean seed production (a) and at the seed harvest times (b). Source: Brazilian National Institute of Meteorology (INMET).

treated with pyraclostrobin + methyl thiophanate + fipronil (Standak Top ${ }^{\circledR}$ ), at the rate of $2.0 \mathrm{~mL}$ of the commercial product per kilogram of seeds, and inoculated with Bradyrhizobium japonicum strains SEMIA 5079 and SEMIA 5080 (Nitragin Cell Tech ${ }^{\circledR}$ ), at the rate of $3.0 \mathrm{~mL}$ of the commercial product per kilogram of seeds. Base fertilization was carried out by applying $350 \mathrm{~kg} \mathrm{ha}^{-1}$ of a $02-30-20$ formulation at sowing. Each experimental unit consisted of four soybean rows of $5.0 \mathrm{~m}$-long, and the useful area were the two central rows of each plot, disregarding $1.0 \mathrm{~m}$ of each edge.

During the soybean growing season, the management of weeds, pests and diseases was performed using the following products: glyphosate, pyraclostrobin + epoxiconazole, azoxystrobin + ciproconazole, teflubenzurom, chlorpyrifos and cypermethrin. All the chemicals used in the present investigation were of analytical grade.

The soybean harvest was carried out manually at eight different periods: $\mathrm{R}_{8}$ phenological stage (when $95 \%$ of pods have the typical coloration of mature pods); $5 ; 10 ; 15 ; 20 ; 25 ; 30$; and 35 days after this stage (Fehr et al. 1971). After harvest, plants were taken to shade and, when the seed moisture content ranged between $12 \%$ and $13 \%$, the soybean plants were mechanically threshed in a grain thresher Vencedora Maqtron ${ }^{\circledR}$ model B-380. After cleaning the seeds, the 1,000-seed weight (Brasil 2009) and seed yield ( $\mathrm{kg} \mathrm{ha}^{-1}$ of seeds), with correction for a $13 \%$ wet basis, were determined. Subsequently, the seeds were sieved through round hole sieves with diameters of $6.00 \mathrm{~mm}$, homogenized, and then the samples for the analyzes were subjected to the mechanical method with the aid of the centrifugal divider. A sample of about $500 \mathrm{~g}$ was separated for each field plot, packed in Kraf-type paper bags, and then kept in a laboratory environment with temperature of $25 \pm 0.8^{\circ} \mathrm{C}$. Afterwards, seeds were submitted to the following tests:

a) Moisture content: the moisture content (\%) of seeds was determined by the oven dry method at $105^{\circ} \mathrm{C}\left( \pm 3{ }^{\circ} \mathrm{C}\right)$, for $24 \mathrm{~h}$ (Brasil 2009), with four replicates of 50 seeds for each sample of each experimental plot;

b) Emergence tests: seedling emergence was carried out in a greenhouse, using four 50 -seed replicates of each treatment. The seeds were placed to germinate in plastic trays $(42 \mathrm{~cm} \times 28 \mathrm{~cm} \times$ $6 \mathrm{~cm})$ containing soil and sand, at the proportion of 2:1 (v/v). The moisture content of the substrate was maintained at $70 \%$ of the field capacity with daily irrigations. The trays were maintained under greenhouse conditions at a temperature of $25{ }^{\circ} \mathrm{C}$ $\left( \pm 2{ }^{\circ} \mathrm{C}\right)$. Seedling counts were performed daily, and the emergence rate index was calculated according to Maguire (1962), at the end of the 14th day;

c) Seedling dry matter: for the determination of the shoot and root dry matter production, all seedlings obtained at the end of the seedling emergence tests (14th day) were removed from the trays, dried in a forced-air circulation oven for three days, at $60^{\circ} \mathrm{C}$, and then weighed. The results were expressed as mg seedling ${ }^{-1}$; 
d) Germination: four 50-seed replicates of each treatment were distributed among three sheets of paper towels moistened with distilled water, in the proportion of 2.5 times their weight. Afterwards, the rolls were taken to a germination chamber at a constant temperature of $25{ }^{\circ} \mathrm{C}$. Evaluations were performed at the 8th day (Brasil 2009);

e) Accelerated aging: seeds were placed on a copper wire mesh inside plastic boxes $(11.0 \mathrm{~cm} \times$ $11.0 \mathrm{~cm} \times 3.0 \mathrm{~cm})$ containing $40 \mathrm{~mL}$ of distilled water (Marcos Filho 1999). The plastic boxes were kept in a BOD incubator at $41^{\circ} \mathrm{C}$, for $48 \mathrm{~h}$. After this period, 200 seeds from each treatment were divided into four replicates of 50 seeds and germinated as previously described (germination test). The evaluation was assessed at the 5th day after sowing, and the percentage of normal seedlings was recorded (Brasil 2009);

f) Electrical conductivity: four 50-seed replicates of each treatment were placed in $300 \mathrm{~mL}$ plastic cups and weighed on an analytical scale (0.001 g accuracy). Then, $75 \mathrm{~mL}$ of distilled water were added to each container. The containers were placed in a BOD incubator at a constant temperature of $25{ }^{\circ} \mathrm{C}$. After $24 \mathrm{~h}$ of incubation, the seeds were gently agitated for homogenization of the solution, and the electrical conductivity was measured with a conductivity meter (MS TECNOPON ${ }^{\circledR}$ mCA150). The results were expressed as $\mu \mathrm{S} \mathrm{cm}^{-1} \mathrm{~g}^{-1}$ (Krzyzanowski et al. 1999);

g) Tetrazolium test: conducted on two subsamples of 50 seeds per treatment. The preconditioning of seeds was carried out on moistened paper towel, for $16 \mathrm{~h}$, at $25^{\circ} \mathrm{C}$. Thereafter, the seeds were transferred to plastic cups with a $0.075 \%$ solution of 2,3,5-triphenyl tetrazolium chloride and stained in a dark chamber at $40{ }^{\circ} \mathrm{C}$, for $3 \mathrm{~h}$. Then, the seeds were washed in running water and each seed was analyzed individually by examining the location and extent of external and internal damages (mechanical damage, weathering and stink bug damage), by cutting longitudinally the seeds along the embryonic axis, and the seed coat was removed (França-Neto et al. 1998);

h) Enzymatic expression: 50 seeds from each treatment were crushed using a TE613/1 (model Rebnal) mill, cooled at $4{ }^{\circ} \mathrm{C}$, in the presence of polyvinylpyrrolidone antioxidant and liquid nitrogen, in a mortar. After milling, the material was stored at $-80{ }^{\circ} \mathrm{C}$, for the enzyme activity analysis. The evaluation of each enzyme was performed by adding $100 \mathrm{mg}$ of seed powder to $300 \mu \mathrm{L}$ of extraction buffer (Tris $0.2 \mathrm{~mol} \mathrm{~L}^{-1} ; \mathrm{pH} 8.0$ ) and $0.1 \%$ of $\beta$-mercaptoethanol, homogenized by vortexing, and, then, kept in a refrigerator for $12 \mathrm{~h}$. The samples were centrifuged at $18,000 \mathrm{rpm}$, at $4{ }^{\circ} \mathrm{C}$, for $30 \mathrm{~min}$ (Alfenas 2006). Prior to extraction, samples were washed for oil removal with ethyl ether and water (Carvalho et al. 2014a). To perform the electrophoretic run, $60 \mu \mathrm{L}$ of the supernatant of the extracted material were applied to the gel channels, and the run was performed in a vertical electrophoresis system model MV20COMP (Omniphor, San Jose, CA, EUA), at $4{ }^{\circ} \mathrm{C}, 150 \mathrm{~V}$, for $6 \mathrm{~h}$. The electrophoresis in polyacrylamide gels (NATIVA-PAGE) was performed in a discontinuous system $(7.5 \%$ of separating gel and $4.5 \%$ of concentration gel). The gel/electrode buffer system used was the Tris-glycine $\mathrm{pH}$ 8.9. At the end of the electrophoretic run, the gels were revealed for the following isoenzyme systems: malate dehydrogenase (EC 1.1.1.37), alcohol dehydrogenase (EC 1.1.1.1), esterase (EC 3.1.1.1), isocitrate lyase (EC 4.1.3.1) and superoxide dismutase (EC 1.15.1.1), according to Alfenas (2006). The evaluation of the enzymatic profiles was performed according to the presence or absence of bands and their intensity.

The experiment was carried out in a randomized block design, with eight harvest times $[0 ; 5 ; 10 ; 15$; $20 ; 25 ; 30$; and 35 days after the $\mathrm{R}_{8}$ stage (when $95 \%$ of pods have the typical coloration of mature pods)] and four replications in the field. Data were assessed by variance analysis (Anova) at $95 \%$, means of harvest times were submitted to regression analysis and significant equations with the highest coefficients of determination ( $F$ test, $p<0.05$ ) were adjusted. The regression analyses were performed using the SigmaPlot 11.0 software for Windows (Systat Software, Inc., San Jose, CA, USA).

\section{RESULTS AND DISCUSSION}

The moisture content of each harvest period did not present significant differences (Table 2). These results are similar to those reported by Lima et al. (2007), who found that there was no statistical difference for this variable, when evaluating the harvest delays in different soybean genotypes.

The 1,000-seed weight and seed yield were not significantly affected by the different harvest times (Table 2). Therefore, it may be inferred that 
harvest delays for up to 35 days after the $\mathrm{R}_{8}$ stage do not affect seeds, in terms of produced quantity. Equivalent results were reported by Pelúzio et al. (2008), who observed that soybean harvest delays are not harmful to the 1,000-seed weight and seed yield. This fact may be explained because the harvest was carried out after the maximum dry matter accumulation of soybean seeds, which is reached at the $\mathrm{R}_{7}$ phenological stage.

Table 2. Mean values of moisture content (MC), 1,000-seed weight $(1,000-\mathrm{W})$ and seed yield obtained at different harvest times for the soybean BRS $820 \mathrm{RR}^{\circledR}$ cultivar.

\begin{tabular}{cccl}
\hline \multirow{2}{*}{ Days after $\mathrm{R}_{8}$} & $\mathrm{MC}$ & $1,000-\mathrm{W}$ & YIELD \\
\cline { 2 - 4 } & $\%$ & $\mathrm{~g}$ & $\mathrm{~kg} \mathrm{ha}^{-1}$ \\
\hline 0 & $10.48^{\mathrm{ns}}$ & $158.50^{\text {ns }}$ & $2,329.00^{\mathrm{ns}}$ \\
5 & 10.50 & 150.75 & $2,231.26$ \\
10 & 10.17 & 152.75 & $2,225.13$ \\
15 & 10.15 & 157.25 & $2,232.34$ \\
20 & 10.42 & 154.75 & $2,106.45$ \\
25 & 10.55 & 158.50 & $2,116.49$ \\
30 & 10.30 & 156.50 & $2,084.98$ \\
35 & 10.32 & 153.00 & $2,134.65$ \\
\hline $\mathrm{CV}(\%)$ & 9.52 & 7.13 & 13.49 \\
\hline
\end{tabular}

${ }^{\mathrm{ns}}$ not significant; $\mathrm{CV}$ : coefficient of variation.
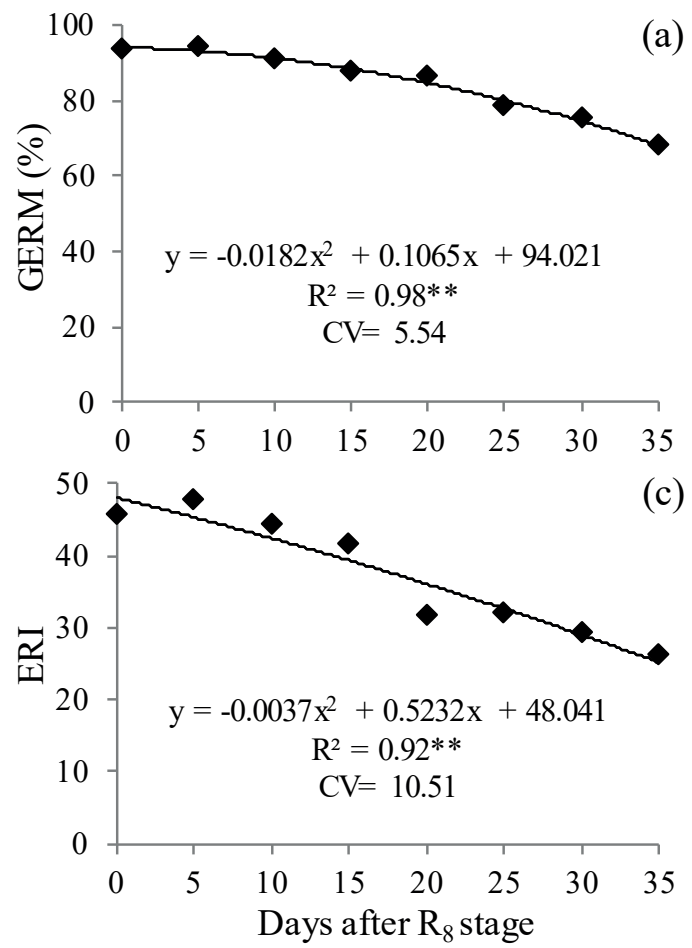

The physiological quality of soybean seeds was affected by harvest delays. A quadratic response to the values for germination (Figure 2a), emergence (Figure 2b), emergence rate index (Figure 2c) and plant dry matter (Figure 2d) was verified. The results obtained indicate that the harvest at the $\mathrm{R}_{8}$ stage resulted in a higher physiological quality of the seeds, but with a tendency of stability of the physiological quality values for up to 10 days of harvest delay. However, a 10-day delay in harvest and subsequent damage from natural seed deterioration resulted in a decrease in the physiological quality of the seeds, which was intensified with the harvest delay of up to 35 days. These results are partially similar to those observed by Xavier et al. (2015), who noticed greater germination rates in seeds harvested at the $\mathrm{R}_{8}$ stage, decreasing thereafter.

The minimum germination of soybean seed lots in Brazil should reach $80 \%$, according to the commercialization standards established (Brasil 2013). Consequently, seeds harvested up to 15 days after the $\mathrm{R}_{8}$ stage present a satisfactory germination rate (Figure 2a). It should be noted that, due to market demands, simply stating the seed germination percentage is not sufficient. Other feature traits, such as seed vigor, emergence field (Figure 2b), emergence

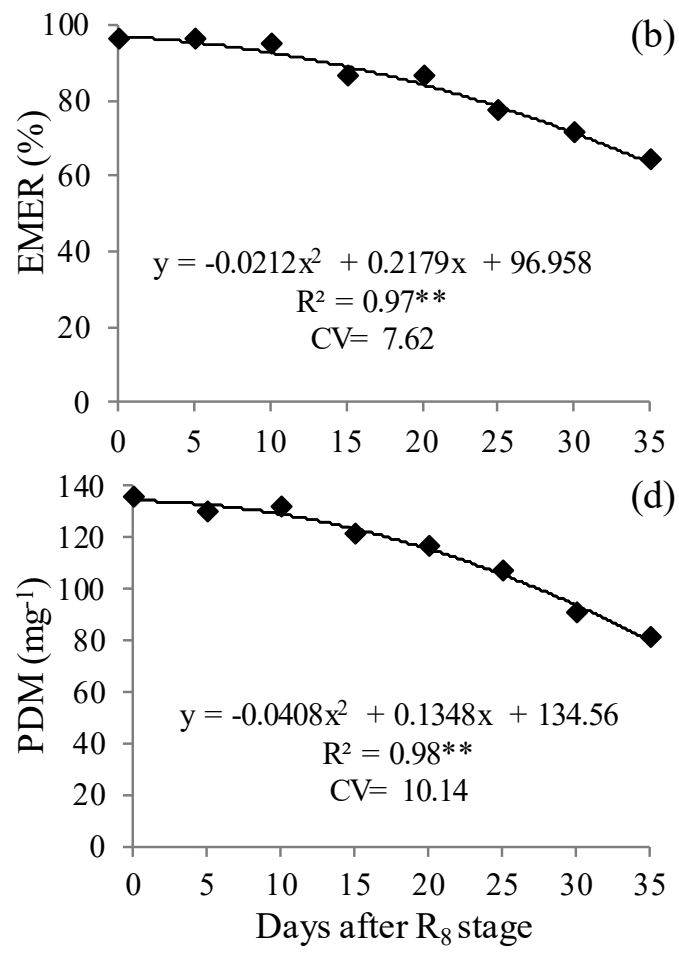

Figure 2. Germination (GERM; a), emergence (EMER; b), emergence rate index (ERI; c) and plant dry matter (PDM; d) obtained at different harvest times for the soybean BRS $820 \mathrm{RR}^{\circledR}$ cultivar. 
rate index (Figure 2c) and plant dry matter (Figure 2d) are also required. For these variables, there was no deleterious effect for up to 10 days of harvest delay.

According to Hampton \& Tekrony (1995), the germination test has some limitations, for example, its inefficiency in detecting differences in high-germination lots and the overestimation of physiological seed potential, since it is conducted under controlled and optimal-for-germination conditions. Such physiological potential tends to decrease as seeds remain in the field for more than 10 days after their full maturity $\left(\mathrm{R}_{8}\right)$ (Figure 2 ). It is likely that the decrease of the physiological seeds quality due to harvest delay is related to the progressive loss of vigor caused by adverse conditions occurred in the field after the $\mathrm{R}_{8}$ stage (Figure 1).

The accelerated aging test indicated that there was a decrease in vigor after 10 days of harvest delay (Figure 3a), as an example of what happened in the previous variables inherent to seed vigor. Pelúzio et al. (2008) reported similar results.

The electric conductivity in soybean seeds was affected by the delay in harvest (Figure $3 b$ ). The results showed a lower physiological potential of the seeds as the harvest delay advances. Regarding the observed values, as an example of what was reported for the other vigor variables, the best electric conductivity results were up to 10 days of harvest delay. It should be noticed that, in soybean seed lots of high vigor, the electric conductivity values must be under $70-80 \mu \mathrm{S} \mathrm{cm}^{-1} \mathrm{~g}^{-1}$ (Vieira \& Krzyzanowski 1999), values registered under 10 days of harvest delay. However, seeds with electric conductivity values up to $90 \mu \mathrm{S} \mathrm{cm}^{-1} \mathrm{~g}^{-1}$ may express a satisfactory performance under adverse field conditions (Vieira et al. 2004). This level was found in seeds with a harvest delay up to 15 days.

The tetrazolium test results concerning vigor (Figure 3c) and viability (Figure 3d) indicate that seeds harvested at the $\mathrm{R}_{8}$ growth stage presented better performances, with $91 \%$ and $95 \%$, respectively. As an example of what was observed for the other physiological quality characteristics, the advancement of the harvest delay period was harmful. The tetrazolium test is the favorite among soybean seed companies in Brazil (França-Neto et al. 1998). This fact is linked to the operation time and test precision, besides pointing out the causes of the physiological seeds quality reduction due to damages caused by soybean stink bugs, humidity deterioration and mechanical damages, which are the main sources of damage impacting soybean crops in Brazil.

After analyzing the damages detected in the tetrazolium test, it was possible to infer that, for the seeds that remain in the field after the $\mathrm{R}_{8}$ stage, there
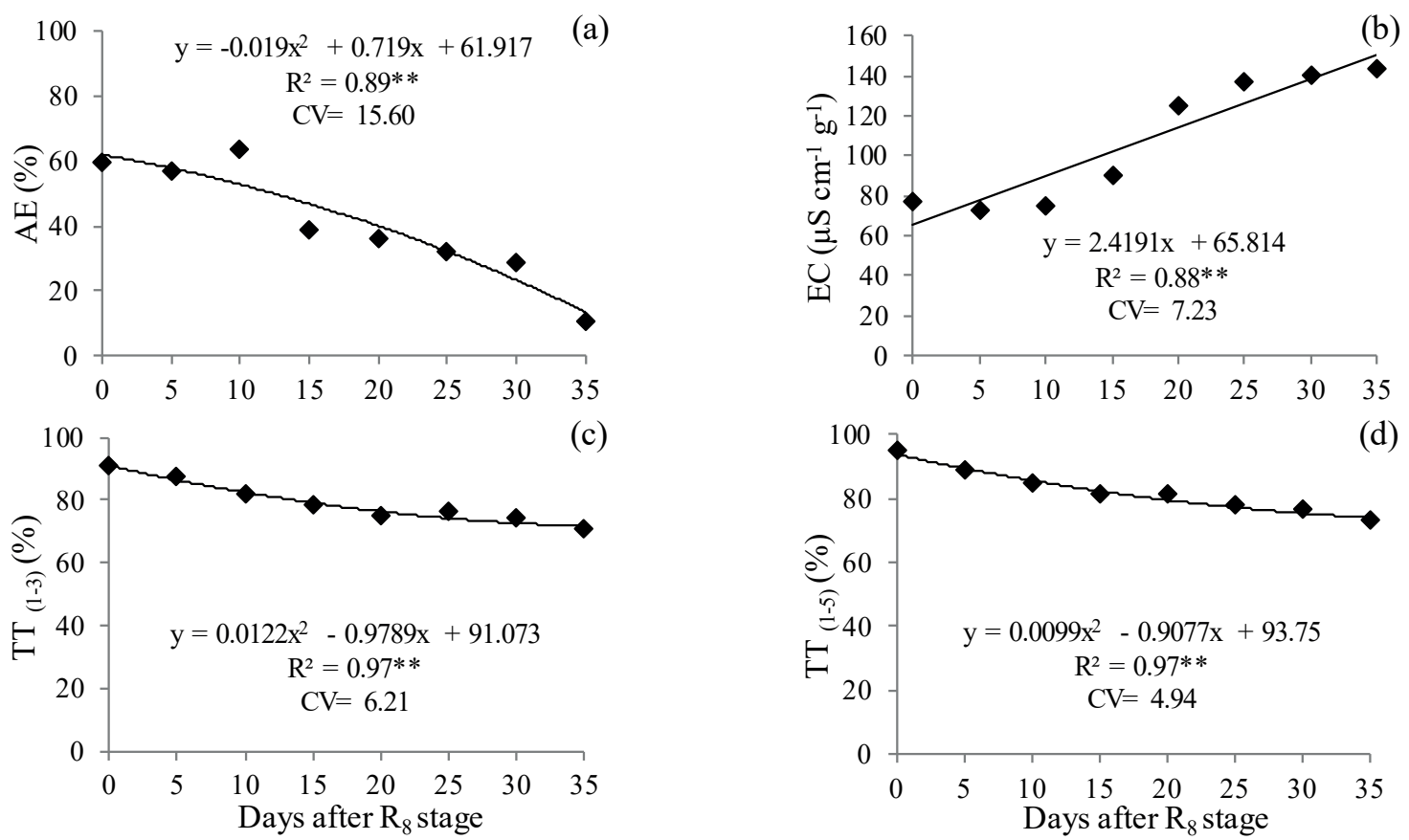

Figure 3. Accelerated aging (AE; a), electrical conductivity $(\mathrm{EC} ; \mathrm{b})$, vigor percentage by the tetrazolium test [TT $\mathrm{T}_{(1-3)}$; $\left.\mathrm{c}\right]$ and viability percentage by the tetrazolium test $\left[\mathrm{TT}_{(1-5)} ; \mathrm{d}\right]$ obtained at different harvest times for the soybean BRS $820 \mathrm{RR}^{\circledR}$ cultivar. 
is a greater reduction of vigor and viability (Figure 3), as well as physiological seed quality (Figure 2). These results were especially due to humidity and soybean stink bug damages (Figure 4), which, at 35 days of harvest delay, reached $9.5 \%$ and $54.5 \%$, respectively. The percentage of seeds damaged by soybean stink bugs increased exponentially as the harvest was delayed after the $\mathrm{R}_{8}$ stage, especially after 20 days (Figure 4). The damages caused by humidity were more relevant to the deterioration after 10 and 15 days of harvest delay (Figure 4) because rainfall was registered in these days (Figure 1), what may have contributed to the occurrence and later evolution of this kind of damage.

Besides the period between the physiological maturity and harvest (Diniz et al. 2013b), the oscillations of humidity conditions, especially in tropical regions, may cause damages in seeds (Castro et al. 2016). According to Marcos Filho (2005), the reduction of seed quality after maturity is caused by oscillations of dry and wet periods, combined with high temperatures. This situation predisposes the occurrence of integument damages, due to the consequences of expansions and contractions after a successive moistening and drying cycle.

For Trumper \& Edelstein (2008), the site of injuries caused by soybean stink bugs is more relevant than the amount, since a bite on the hypocotyl makes germination impossible. On the other hand, several bites on the cotyledons reduce its vigor and emergence. However, they do not affect germination.

For the expression of malate dehydrogenase, differences were found after 20 days of harvest delay (Figure 5a). Thereafter, the malate dehydrogenase activity decreased, especially at 25 days after the $R_{8}$ stage. In the germination test, it was noticed, at 25 days after the $\mathrm{R}_{8}$ stage, that the soybean seeds were improper for commercialization (Figure 2). Therefore, the permanence of seeds in the field promotes the loss of their

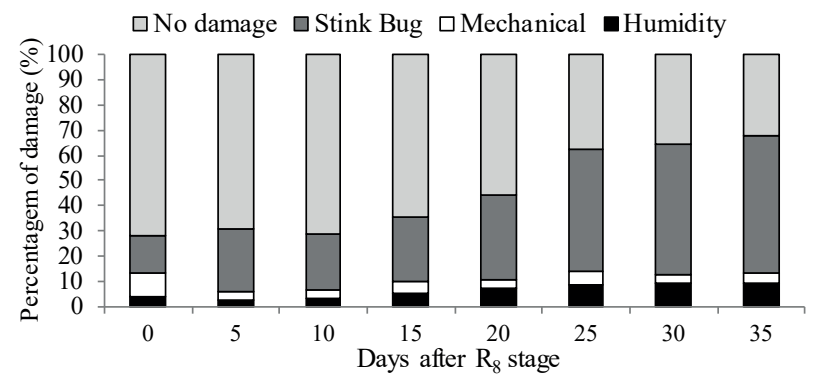

Figure 4. Damages caused and the respective percentages (\%) observed at the tetrazolium test for each harvest time. physiological quality, due to the deterioration process. For Copeland \& McDonald (2001), deterioration causes changes in the decrease of the respiratory activity, degradation and inactivation of enzymes.

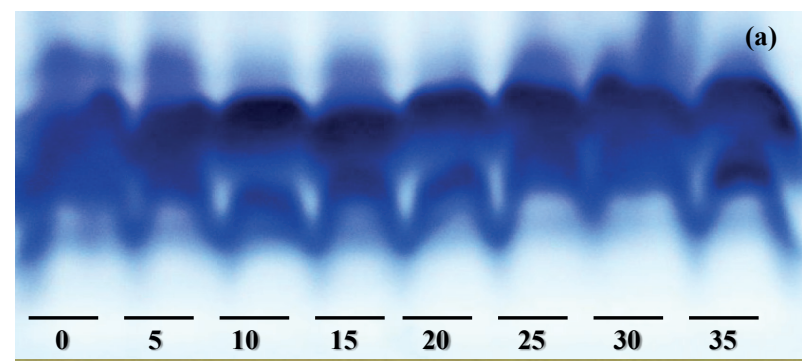

(b)

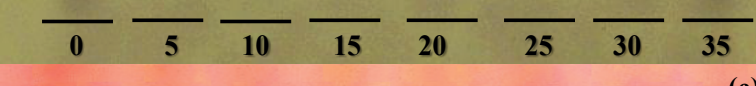

(c)

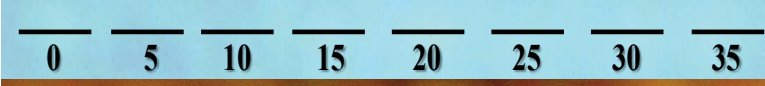

(e)

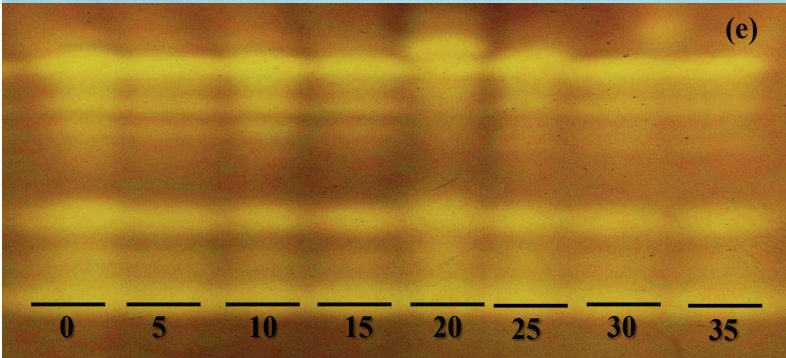

Figure 5. Changes in isoenzymatic expression of malate dehydrogenase (a), alcohol dehydrogenase (b), esterase (c), isocitrate lyase (d) and superoxide dismutase (e), in soybean seeds of the BRS $820 \mathrm{RR}^{\circledR}$ cultivar harvested at different periods: $\mathrm{R}_{8}$ stage $(0)$; $5 ; 10 ; 15 ; 20 ; 25 ; 30$; and 35 days after this stage. 
The higher expression of alcohol dehydrogenase was observed in seeds harvested at the $\mathrm{R}_{8}$ stage (Figure 5b), which usually present a superior physiological quality, and, as the harvest delay period advanced, lower expressions were detected. The lower expression of this enzyme was noticed after 5 days of harvest delay and, usually, the reduction of seed vigor was noticed after 10 days of harvest delay (Figures 2 and 3), what makes possible to infer, in some cases, that isoenzymatic changes occur before physiological quality changes. According to Veiga et al. (2010), the alcohol dehydrogenase transforms acetaldehyde in ethanol, a compound of lower toxicity, and reduces the deterioration process rate. Accordingly, seeds that present a higher expression of such enzyme have a better physiological quality, as proven by the physiological tests in this study and also confirmed by Carvalho et al. (2014a). Carvalho et al. (2014c) also observed a higher alcohol dehydrogenase expression in seeds that presented a better physiological quality.

For the esterase isoenzyme expression, a reduction was observed after 15 days of harvest delay, with more prominent effects after 30 days (Figure 5c). The seed vigor characteristics decreased after a delay of 10 days and germination especially after 15 days (Figures 2 and 3). Esterase is linked to lipid degradation, an important process for soybean seed germination (Carvalho et al. 2014c). The greatest increase in the esterase enzyme expression may be related to greater germination values. Such data are observed in the physiological quality tests (Figures 2 and 3). As the permanence of the seeds increased in the field, the physiological quality of the seeds and the esterase expression decreased. Vieira et al. (2013) also confirmed the correlation between the esterase activity reduction and the lower vigor level of soybean seeds.

For the isocitrate lyase enzyme, a lower activity was reported at 20 days after the $R_{8}$ stage, as well as a prominent reduction in 25 days of harvest delay and onwards (Figure 5d). According to Carvalho et al. (2014a), the isocitrate lyase participates in the glyoxylate cycle, in the glyoxysomes, which is involved in the metabolism of lipids stored in oil seeds like soybean. With a reduced isocitrate lyase enzyme activity, the transformation of lipids in sugars is reduced in soybean seeds and, consequently, germination and/or emergence is affected. This fact affected the seed quality with delays of 15 days and onwards, as registered in the physiological tests (Figures 2 and 3).
A greater expression of the superoxide dismutase was observed in seeds harvested at the $\mathrm{R}_{8}$ stage (Figure 5e). After 5 days of harvest delay, a reduction of such isoenzyme expression was verified, prominent especially at 20 days after the $\mathrm{R}_{8}$ stage (Figure 5e). The decreases of the physiological seed quality were observed especially at 15 days after the $\mathrm{R}_{8}$ stage (Figures 2 and 3), for example, the elevation of the electric conductivity values observed between 15 and 20 days after the $\mathrm{R}_{8}$ stage (Figure $3 \mathrm{~b}$ ). These facts are related to the formation and accumulation of oxygen reactive species, which culminated in the lower physiological seeds potential in these treatments. The maintenance of the antioxidant isoenzyme activity systems, such as the superoxide dismutase and peroxidase, is relevant, because they remove and reduce reactive oxygen species that may cause cellular damages and affect the seeds quality (Møller et al. 2007, Deuner et al. 2011, Carvalho et al. 2014a).

\section{CONCLUSIONS}

1. Delaying harvest for up to 35 days after the $R_{8}$ growth stage does not affect the 1,000-seed weight and seed yield of soybean crops. The delayed harvest from the $\mathrm{R}_{8}$ stage results in an increased damage from soybean stink bugs and moisture. Delaying soybean harvest for 10 or 15 days after the $\mathrm{R}_{8}$ growth stage might impair the seed vigor and germination potential;

2. Seeds harvested with a delay after the $\mathrm{R}_{8}$ growth stage have lower expressions of the following isoenzymatic systems: malate dehydrogenase, alcohol dehydrogenase, esterase, isocitrate lyase and superoxide dismutase, especially after 15 days of harvest delay.

\section{REFERENCES}

ALFENAS, A. C. Eletroforese e marcadores bioquímicos em plantas e microrganismos. Viçosa: Ed. da UFV, 2006.

BRASIL. Ministério da Agricultura, Pecuária e Abastecimento. Padrões para produção e comercialização de sementes de soja (Glycine max (L.) Merrill). Instrução Normativa $^{\circ} 45$, de 17 de setembro de 2013. Diário Oficial da União, Brasília, DF, 20 set. 2013. Seção 1, p. 29.

BRASIL. Ministério da Agricultura, Pecuária e Abastecimento. Regras para análise de sementes. Brasília, DF: MAPA/ACS, 2009. 
CARVALHO, E. R. et al. Alterações isoenzimáticas em sementes de cultivares de soja em diferentes condições de armazenamento. Pesquisa Agropecuária Brasileira, v. 49, n. 12, p. 967-976, 2014a.

CARVALHO, E. R. et al. Qualidade fisiológica de sementes de soja convencional e transgênica RR produzidas sob aplicação foliar de manganês. Bragantia, v. 73, n. 3, p. 219-228, 2014b.

CARVALHO, E. R. et al. Enzyme activity in soybean seeds produced under foliar application of manganese. Ciência e Agrotecnologia, v. 38, n. 4, p. 317-327, 2014 c.

CASTRO, E. M. et al. Physiological quality of soybean seeds produced under artificial rain in the pre-harvesting period. Journal of Seed Science, v. 38, n. 1, p. 14-21, 2016.

COMPANHIA NACIONAL DE ABASTECIMENTO (Conab). Acompanhamento da safra brasileira: grãos, décimo primeiro levantamento, setembro 2017. Brasília, DF: Conab, 2017.

COPELAND, L. O.; MCDONALD, M. B. Principles of seed science and technology. New York: Chapman and Hall, 2001.

DEUNER, C. et al. Viabilidade e atividade antioxidante de sementes de genótipos de feijão-miúdo submetidos ao estresse salino. Revista Brasileira de Sementes, v. 33, n. 4, p. 711-720, 2011.

DINIZ, F. O. et al. Incidence of pathogens and field emergence of soybean seeds subjected to harvest delay. Journal of Seed Science, v. 35, n. 4, p. 478-484, 2013 a.

DINIZ, F. O. et al. Physiological quality of soybean seeds of cultivars submitted to harvesting delay and its association with seedling emergence in the field. Journal of Seed Science, v. 35, n. 2, p. 147-152, 2013 b.

FEHR, W. R. et al. Stage of development descriptions for soybeans, Glycine $\max (\mathrm{L}$.) Merrill. Crop Science, v. 11, n. 6, p. 929-931, 1971.

FRANÇA-NETO, J. B. et al. O teste de tetrazólio em sementes de soja. Londrina: Embrapa, 1998.

GRIS, C. F. et al. Qualidade fisiológica e teor de lignina no tegumento de sementes de soja convencional e transgênica RR submetidas a diferentes épocas de colheita. Ciência e Agrotecnologia, v. 34, n. 2, p. 374-381, 2010.

HAMPTON, J. G.; TEKRONY, D. M. Handbook of vigor test methods. 3. ed. Zurich: ISTA, 1995.

KRZYZANOWSKI, F. C. et al. Vigor de sementes: conceitos e testes. Londrina: Abrates, 1999.

LIMA, W. A. A. et al. Retardamento de colheita como método de diferenciação de genótipos de soja para qualidade de sementes. Revista Brasileira de Sementes, v. 29, n. 1, p. 186-192, 2007.
MAGUIRE, J. D. Speed of germination-aid in selection and evaluation for seedling emergence and vigor. Crop Science, v. 2, n. 2, p. 176-177, 1962.

MARCOS FILHO, J. Fisiologia de sementes de plantas cultivadas. Piracicaba: FEALQ, 2005.

MARCOS FILHO, J. Teste de envelhecimento acelerado. In: KRZYZANOWSKI, F. C.; VIEIRA, R. D.; FRANÇA NETO, J. B. (Eds.). Vigor de sementes: conceitos e testes. Londrina: Abrates, 1999. p. 24-32.

MINUZZI, A. et al. Qualidade de sementes de quatro cultivares de soja, colhidas em dois locais no estado do Mato Grosso do Sul. Revista Brasileira de Sementes, v. 32, n. 1, p. 176-185, 2010.

MØLLER, I. M. et al. Oxidative modifications to cellular components in plants. Annual Review of Plant Biology, v. 58, n. 1, p. 459-481, 2007.

PELÚZIO, J. M. et al. Influência da dessecação química e retardamento de colheita na qualidade fisiológica de sementes de soja no sul do estado do Tocantins. Bioscience Journal, v. 24, n. 2, p. 77-82, 2008.

SEDIYAMA, T. Produtividade da soja. Londrina: Mecenas, 2016.

TRUMPER, E. V.; EDELSTEIN, J. D. El complejo de chinches fitofagos en soja: revision y avances en el estudio de su ecologia y manejo. Fountain Valley: INTA, 2008.

VEIGA, A. D. et al. Influência do potássio e da calagem na composição química, qualidade fisiológica e na atividade enzimática de sementes de soja. Ciência e Agrotecnologia, v. 34, n. 4, p. 953-960, 2010.

VIEIRA, B. G. T. L. et al. Biochemical alterations in soybean seeds with harvesting time and storage temperature. Journal of Food, Agriculture and Environment, v. 11, n. 5, p. 887-891, 2013.

VIEIRA, R. D. et al. Electrical conductivity of the seed soaking solution and soybean seedling emergence. Scientia Agricola, v. 61, n. 2, p. 164-168, 2004.

VIEIRA, R. D.; KRZYZANOWSKI, F. C. Teste de condutividade elétrica. In: KRZYANOWSKI, F. C.; VIEIRA, R. D.; FRANÇA NETO, J. B. (Eds.). Vigor de sementes: conceitos e testes. Londrina: Abrates, 1999. p. 1-26.

XAVIER, T. S. et al. Época de colheita na qualidade de sementes de genótipos de soja. Comunicata Scientiae, v. 6 , n. 2, p. 241-245, 2015.

ZUFFO, A. M. et al. Physiological and sanitary quality of soybean seeds harvested at different periods and submitted to storage. Pesquisa Agropecuária Tropical, v. 47, n. 3, p. 312-320, 2017. 